\title{
FAKTOR PENYEBAB PERILAKU SODOMI PADA REMAJA \\ (STUDI DI LEMBAGA PEMBINAAN KHUSUS ANAK PEKANBARU)
}

\author{
Ingrid Weddy Viva Febrya, M. Pd
}

\begin{abstract}
Deviant behavior of sodomy is not only did by man but also did by adolescents. Sodomies in young age would serving their punishment at the Children Correctional Institution (LPKA), which was previously called children correctional institution. This research was conducted to determine what factors are behind the sodomy behavior in adolescents. The research was conducted in January-March 2020, located in LPKA Pekanbaru, Penitentiary street No.04, Muara Fajar, Rumbai sub district, Pekanbaru City, Riau. This research used descriptive qualitative method. Data obtained qualitatively and will present in a descriptive way. The research subjects were two children assisted by inmates with sodomy cases. Subject characteristics consist of: 1) age about 15 years old, 2) last education on Primary School and 3) sodomy cases. Data collection were done by observation, in-depth interviews and documentation. Data analysis used triangulation, which analyzed the results of interviews between subjects, LPKA officers and the subject's family. The results of this research found that the factors causing adolescents to do sodomy are: 1. Lack of parental supervision, 2. Previous perpetrators were victims of sodomy committed by adults and felt vengeful so that they took it out on younger children, 3. Cause of porn videos of homo sexual that watched by the perpetrators.
\end{abstract}

Keywords : Sodomy, Child Inmates, Children Correctional Institution.

\section{Pendahuluan}

Kejahatan sodomi merupakan suatu tindak kriminal yang saat ini mulai meningkat. Pelaku sodomi yang awalnya dilakukan oleh laki-laki dewasa, saat ini mulai juga dilakukan oleh remaja. Berdasarkan data yang dikumpulkan oleh Pusat Data dan Informasi Komisi Nasional
Perlindungan Anak Indonesia tahun 2010 hingga tahun 2014 tercatat sebanyak 21.869.797 kasus pelanggaran hak anak, yang tersebar di 34 provinsi, dan 179 kabupaten dan kota. Sebesar $42-58 \%$ dari pelanggaran hak anak itu, katanya, merupakan kejahatan seksual terhadap anak. Selebihnya adalah kasus kekerasan. 
fisik, dan penelantaran anak. Data dan korban kejahatan seksual terhadap anak setiap tahun terjadi peningkatan. Pada 2010, ada 2.046 kasus, diantaranya $42 \%$ kejahatan seksual. Pada 2011 terjadi 2.426 kasus (58\% kejahatan seksual), dan 2012 ada 2.637 kasus (62\% kejahatan seksual). Pada 2013, terjadi peningkatan yang cukup besar yaitu 3.339 kasus, dengan kejahatan seksual sebesar $62 \%$. Sedangkan pada 2014 (Januari-April), terjadi sebanyak 600 kasus atau 876 korban, diantaranya 137 kasus adalah pelaku anak. Komisi perlindungan anak Indonesia juga menemukan banyak aduan kekerasan pada anak pada tahun 2010. Dari 171 kasus pengaduan yang masuk, sebanyak 67,8 persen terkait dengan kasus kekerasan. Dan dari kasus kekerasan tersebut yang paling banyak terjadi adalah kasus kekerasan seksual yaitu sebesar 45,7 persen (53 kasus).

Komisi nasional perlindungan anak (Komnas Anak) mencatat, jenis kejahatan anak tertinggi sejak tahun 2007 adalah tindak sodomi terhadap anak. Dan para pelakunya biasanya adalah guru sekolah, guru privat termasuk guru ngaji, dan sopir pribadi. Tahun 2007, jumlah kasus sodomi anak, tertinggi di antara jumlah kasus kejahatan anak lainnya. Dari 1.992 kasus kejahatan anak yang masuk ke Komnas Anak tahun itu, sebanyak 1.160 kasus atau 61,8 persen, adalah kasus sodomi anak. Dari tahun 2007 sampai akhir Maret 2008, jumlah kasus sodomi anak sendiri sudah naik sebesar 50 persen. Komisi Nasional Perlindungan Anak telah meluncurkan Gerakan Melawan Kekejaman Terhadap Anak, karena meningkatnya kekerasan tiap tahun pada anak. Pada tahun 2009 lalu ada 1998 kekerasan meningkat pada tahun 2010 menjadi 2335 kekerasan dan sampai pada bulan maret 2011 ini paling tidak dari pantauan Komisi Nasional Perlindungan Anak ada 156 kekerasan seksual khususnya sodomi pada anak.

Berdasarkan data dari KPAI daerah Riau tahun 2019, lebih dari 104 anak yang tersebar diseluruh wilayah Kabupaten/kota di provinsi Riau mengalami korban kekerasan dan pelecehan seksual dengan cara 
perkosaan maupun sodomi. Ratusan anak yang dominan berumur dibawah 10 tahun menjadi korban kejahatan seksual yang dilakukan oleh pria remaja maupun dewasa. Bahkan ada beberapa pelaku masih tergolong usia anak. Kajian dan penelitian terhadap kasus sodomi biasanya hanya dilihat dari perspektif korban. Pelaku sodomi yang berusia anak sampai remaja sesungguhnya juga membutuhkan perhatian yang serius dari pemerintah dan masyarakat. Usia anak sampai remaja merupakan usia dimana mereka dalam proses pengembangan dirinya, sehingga saat dalam proses tersebut mengalami gangguan maka hasil dari pengembangan diri mereka juga tidak berjalan baik.

Masa remaja merupakan masa transisi dari usia anak menuju dewasa. Pada masa ini anak rentan mengalami berbagai permasalahan bahkan dapat mengarah pada tindakan kriminal. Berdasarkan Sarwono (2012) dalam bukunya Psikologi remaja, mengatakan bahwa menurut WHO usia remaja adalah antara $14-20$ tahun. Dalam rentang masa usia ini, remaja banyak dihadapkan pada berbagai permasalahan. Remaja seharusnya menjalani peran sesuai pertumbuhan dan perkembangan fisik dan psikologisnya. Sekiranya terdapat gangguan dalam proses tersebut maka remaja akan mengalami konflik baik dengan dirinya sendiri maupun konflik di luar diri.

Remaja yang berkonflik dengan hukum akan menjalani masa hukuman di Lembaga Pembinaan Khusus Anak (LPKA). Saat ini LPKA kls II Pekanbaru per tahun 2019 berisi 97 anak, terdiri dari kasus penggelapan, pencurian, perlindungan anak, narkotika, penganiayaan, penadahan, pembunuhan dan kesusilaan. Berikut adalah tabel data jumlah penghuni LPKA Pekanbaru. 
Tabel 1 : Data jumlah Warga Binaan anak berdasarkan kasus di LPKA

Pekanbaru Tahun 2019

\begin{tabular}{|c|c|c|}
\hline No. & Kasus & Jumlah \\
\hline $\mathbf{1}$ & Penggelapan & 1 \\
\hline $\mathbf{2}$ & Pencurian & 36 \\
\hline $\mathbf{3}$ & Perlindungan Anak & 24 \\
\hline $\mathbf{4}$ & Narkotika & 9 \\
\hline $\mathbf{5}$ & Penganiayaan & 6 \\
\hline $\mathbf{6}$ & Penadahan & 1 \\
\hline $\mathbf{7}$ & Pembunuhan & 3 \\
\hline $\mathbf{8}$ & Kesusilaan & 2 \\
\hline
\end{tabular}

\section{Sumber: Seksi Pembinaan dan Pendidikan LPKA Pekanbaru 2019.}

Pada tabel di atas terlihat bahwa kasus perlindungan anak memiliki jumlah terbanyak kedua, dimana terdapat 2 kasus penyimpangan seksual yang dilakukan oleh anak yaitu sodomi.

Penyimpangan Seksual merupakan tingkah laku seksual yang tidak dapat diterima oleh masyarakat dan tidak sesuai dengan tata cara serta norma agama, yang mana cara untuk mendapatkan kenikmatan seksual ini dengan jalan yang tidak wajar salah satunya adalah sodomi. Sodomi ialah penyimpangan seksual terhadap pasangan seks yang berjenis kelamin sama dimana hubungan seksual dilakukan melalui anus. Pelaku sodomi yang menjalani hukuman di LPKA Pekanbaru berusia 14 dan 15 tahun. Berdasarkan latar belakang di atas maka dirasa perlu untuk melakukan penelitian guna mengetahui faktor penyebab remaja melakukan perilaku sodomi, khususnya pada pelaku yang kini berada di LPKA Pekanbaru.

\section{Metode Penelitian}

Penelitian ini dilakukan selama tiga bulan, yaitu Januari - Maret 2020. Tempat penelitian berada di LPKA Pekanbaru jalan Lembaga Permasyarakatan No.04, Muara Fajar, Kec. Rumbai, Kota Pekanbaru, Riau. 
Penelitian ini menggunakan design penelitian deskriptif kualitatif. Penelitian menggunakan pendekatan kualitatif dengan metode studi kasus. Pendekatan kualitatif menganggap bahwa manusia adalah makhluk yang aktif, yang mempunyai kebebasan, kemauan, yang perilakunya hanya dapat dipahami dalam konteks budayanya, dan yang perilakunya tidak didasarkan pada hukum sebab akibat (Alsa, 2003).

Data primer didapatkan secara kualitatif dan dipaparkan melalui cara deskriptif. Subyek penelitian adalah dua orang warga binaan anak dengan kasus sodomi. Karakteristik subyek terdiri dari :1) usia 15 tahun, 2)pendidikan terakhir SD dan 3)kasus sodomi. Pengumpulan data dilakukan dengan cara observasi, wawancara mendalam dan dokumentasi. Analisis data menggunakan triangulasi, yaitu menganalisis hasil wawancara antara subyek, petugas lpka dan keluarga subyek.

Pengambilan data pertama kali dilakukan dengan cara observasi. Tujuan observasi adalah untuk mendapatkan data awal terkait jumlah, data diri seperti nama, usia, vonis, masa menjalani hukuman dan pendidikan terakhir subyek. Wawancara mendalam terhadap subyek penelitian dilakukan sebanyak lima kali pertemuan. Wawancara terhadap petugas lpka dilakukan satu kali dan wawancara terhadap keluarga subyek dilakukan satu kali. Khusus wawancara keluarga subyek dilakukan pada saat kunjungan. Pengolahan data dilakukan dengan cara mengumpulkan data primer dan sekunder, setelah itu dilakukan analisa data untuk mendapatkan hasil penelitian.

\section{Hasil dan Pembahasan}

Menurut Wikipedia, sodomi adalah istilah hukum yang merujuk pada tindakan seks tidak alami, yang terdiri dari seks oral atau anal, atau semua bentuk pertemuan alat non kelamin dengan alat kelamin, baik dilakukan secara heteroseksual, homoseksual atau antara manusia dan hewan. Istilah ini berasal dari bahasa latin, yaitu peccatum Sodomiticum, atau "dosa kaum Sodom". Istilah sodomi berlatar belakang dari kisah kaum Sodom pada masa nabi Luth AS. 
Dalam Islam, dikenal dengan dua istilah, yaitu Liwath (gay) dan Sihaaq (lesbian). Liwath (gay) adalah perbuatan yang dilakukan oleh lakilaki dengan cara memasukan dzakar (penis)nya kedalam dubur laki-laki lain (Sayyid Sabiq, Fiqhu as-Sunnah, Juz 4/hal. 51). Untuk pelaku liwath ada peringatan dalam Al Quran dan Hadits. Al Quran surat Al-A'raf ayat 80-81 menyatakan liwath sebagai perbuatan keji.. Al Quran juga menjelaskan sanksi Allah bagi kaum Luth, yakni bahwa Allah SWT memberi sanksi kepada mereka dengan khasf (dilempar batu hingga mati). (QS Hûd [11]: 82). Sedangkan menurut Sunnah, telah diriwayatkan oleh Muhammad bin Ishaq dari 'Amru bin 'Amru dan Nabi Saw bahwa beliau bersabda, "Terlaknatlah orang yang mengerjakan perbuatannya kaum Nabi Luth”.

Perilaku sodomi merupakan suatu bentuk gangguan orientasi seksual bahkan menjurus tindak kriminal. Sodomi adalah salah satu bentuk pelecehan seksual yang termasuk ke dalam tindak kejahatan. Dikatakan sebagai kejahatan karena hal ini merugikan korban, baik secara fisik maupun mental. Secara fisik memang mungkin tidak ada hal yang harus dipermasalahkan pada anak yang menjadi korban kekerasan seksual, tapi secara psikis bisa menimbulkan ketagihan, trauma, bahkan pelampiasan dendam (Noviana, 2015).

\section{Kekerasan Seksual Terhadap Anak}

Menurut Ricard J. Gelles ( dalam Hurairah, 2012), kekerasan terhadap anak merupakan perbuatan disengaja yang menimbulkan kerugian atau bahaya terhadap anak-anak baik secara fisik maupun emosional. Bentuk kekerasan terhadap anak dapat diklasifikasikan menjadi kekerasan secara fisik, kekerasan secara psikologis, kekerasan secara seksual dan kekerasan secara sosial. Kekerasan seksual terhadap anak menurut End child prostitution in Asia tourism (ECPAT), merupakan hubungan atau interaksi antara seorang anak dengan orang yang lebih tua atau dewasa seperti orang asing, saudara sekandung atau orang tua dimana anak dipergunakan sebagai objek pemuas kebutuhan seksual pelaku. Perbuatan ini dilakukan dengan paksaan, 
ancaman, suap, tipuan bahkan tekanan (Sari, 2009). Weber dan Smith (2010) mengungkapkan bahwa dampak jangka panjang kekerasan seksual terhadap anak yaitu anak yang menjadi korban kekerasan seksual pada masa kanak-kanak memiliki potensi untuk menjadi pelaku kekerasan seksual dikemudian hari. Ketidak berdayaan korban saat menghadapi tindak kekerasan seksual dimasa kanakkanak, tanpa disadari digeneralisasi dalam persepsi mereka bahwa tindakan atau perilaku seksual bisa dilakukan kepada seseorang yang lemah dan tidak berdaya.

Sodomi merupakan kekerasan seksual yang juga dapat menyebabkan trauma dan rasa malu mendalam pada korban. Pelecehan seksual yang kasusnya kebanyakan menimpa usia kanak-kanak dan remaja ini dapat membawa dampak jangka panjang, bahkan seumur hidup, pada korban.

Terkadang, orang yang pernah mengalami pelecehan seksual di masa kanak-kanak atau remaja sulit untuk mencari bantuan dan mengungkapkan kejahatan seks yang mereka terima. Rasa malu dan minimnya bantuan inilah yang kadang bisa membuat korban jadi trauma, mengalami gangguan kecemasan dan depresi seumur hidup. Seorang psikiater, dr. Elly Ingkriwang, Sp.Kj, menyatakan bahwa korban bisa menjadi penerus pelaku sodomi. Bisa jadi ada sensasi rasa senang yang menyebabkan ketagihan saat melakukan seks anal sehingga korban akan mengulanginya.

Adanya rasa dendam juga bisa menjadi salah satu faktor mengapa korban sodomi tetap ada. Tak ayal, ini disebabkan karena korban hendak membalas dendam pada orang lain. Rasa dendam masa lalu yang tidak tersalurkan dan dipendam sendirian, lama-kelamaan akan memuncak. Inilah yang menurut dr. Elly bisa membuat seseorang yang tadinya korban menjadi pelaku sodomi. Korban ingin tidak hanya dirinya saja yang pernah disodomi, itu sebabnya ia akan melakukannya pada orang lain agar ada yang senasib.

\section{Lingkungan Ikut Berpengaruh Pada} Terjadinya Kasus Sodomi

Faktor lingkungan terkadang juga mempengaruhi munculnya 
perilaku ini. Ketika anak sering tidak berada dalam pengawasan orang tua, resiko terjadinya kekerasan lebih besar. Lingkungan dimana anak tidak berada dalam pengawasan orang tua biasanya menjadi peluang yang lebih besar untuk predator anak melakukan aksinya.

Menurut childtrauma.org, di Amerika Serikat satu dari tiga wanita dan satu dari lima pria telah menjadi korban pelecehan seksual sebelum usia 18 tahun. Sementara itu, menurut data yang didapat dari situs Kominfo, terdapat 1.380 kasus kekerasan seks usia anak pada 2013. Sebanyak 30\%nya adalah kasus sodomi. Beberapa data statistik menunjukkan bahwa anak-anak tiga kali lebih mungkin menjadi korban sodomi daripada orang dewasa. Bahkan di banyak kasus, sodomi lebih mungkin dilakukan oleh keluarga, tetangga, atau bahkan orang terdekat yang tidak disangka-sangka.

Pengertian Pencabulan, Serangan Seksual Dan Pelecehan Seksual. Konsep Pencabulan

Pencabulan, merupakan suatu bentuk perilaku melecehkan anak-anak.
Pencabulan digunakan untuk menggambarkan perilaku terhadap anak-anak, bukan orang dewasa. Pencabulan dapat mencakup banyak hal yang berbeda, dari menyentuh korban secara seksual, memaksa korban menyentuh pelaku secara seksual, hingga memaksa korban melihat organ tubuh seksual atau kegiatan seksual. Pencabulan pada anak-anak adalah tindakan kriminal.

\section{Konsep Serangan seksual}

Istilah serangan seksual dapat digunakan untuk menggambarkan beberapa tindakan kejahatan yang sifatnya seksual, mulai dari menyentuh dan mencium, menggesek, meraba atau memaksa korban menyentuh pelaku secara seksual. Namun serangan seksual beririsan dengan pemerkosaan karena istilah itu mencakup pemerkosaan.

Peneliti bidang sosial dan perilaku sering menggunakan istilah kekerasan seksual. Istilah ini jauh lebih luas daripada serangan seksual. Kekerasan seksual mencakup tindakan yang secara hukum tidak termasuk kriminal tapi membahayakan dan menimbulkan trauma. 
Kekerasan seksual mencakup penggunaan janji palsu, tekanan terusmenerus, kata-kata yang melukai, maupun ancaman terhadap reputasi seseorang untuk memaksa adanya tindakan seksual. Istilah ini juga mencakup tindakan non-sentuhan seperti catcall dan siulan, yang dapat membuat perempuan merasa diobjektifikasi dan dirugikan.

Kekerasan seksual mencakup penyebaran gambar-gambar tidak senonoh secara elektronis tanpa persetujuan, mempertunjukkan alat kelamin atau secara sembunyisembunyi melihat orang lain sedang telanjang atau melakukan hubungan seks.

\section{Konsep Pelecehan seksual}

Pelecehan seksual adalah istilah yang lebih luas dibanding serangan seksual, istilah ini mencakup tiga kategori perilaku yang tidak dibolehkan, yaitu : 1) pemaksaan seksual - secara legal disebut "pelecehan quid pro quo" - yang mengacu pada upaya implisit atau eksplisit untuk membuat suatu kondisi terkait pekerjaan bergantung pada perilaku seksual. Skenario klasik "tidur dengan saya atau kamu dipecat" adalah contoh pemaksaan seksual. Perilaku ini adalah bentuk yang paling umum dikenali sebagai pelecehan seksual, akan tetapi juga yang paling jarang, 2) perhatian seksual yang tidak diinginkan: sentuhan, pelukan, elusan, ciuman yang tidak diinginkan, tekanan terus-menerus untuk melakukan kencan atau tindakan seksual. Patut dicatat bawah pendekatan romantis atau seksual dapat bervariasi dalam lingkungan kerja, tidak semuanya adalah pelecehan, 3) pelecehan gender, yaitu tindakan yang merendahkan orang lain terkait gender, namun tidak melibatkan ketertarikan seksual. Pelecehan gender bisa termasuk istilah dan gambar seksual yang kasar, misalnya komentar merendahkan terkait tubuh atau kegiatan seksual, grafiti yang merendahkan perempuan atau laki-laki. Seringnya, perilaku ini sepenuhnya seksis, misalnya komentar bahwa seorang perempuan tidak pantas memimpin atau laki-laki tidak bisa mengurus anak. Tindakan semacam ini termasuk pelecehan "seksual" karena 
berdasarkan seks (jenis kelamin), bukan karena terkait seksualitas.

permasyarakatan dan tata tertib lembaga permasyarakatan serta melakukan urusan tata usaha. Selain

\section{Konsep Lembaga Pembinaan} Khusus Anak (LPKA)

LPKA merupakan suatu lembaga yang sebelumnya bernama Lapas Anak. Tempat ini adalah suatu tempat dimana anak yang berkonflik dengan hukum dititipkan. Saat ini penggunaan kata lapas dianggap tidak sesuai dengan karakteristik anak dimana anak seharusnya mendapatkan pembinaan bukannya hukuman. LPKA memiliki tugas pokok yaitu melakukan pembimbingan dan pembinaan kepada setiap warga binaan anak, yang berupa pembinaan kerohanian, kepribadian, dan sosial. Disamping itu dilakukan pemeliharaan keamanan lembaga itu warga binaan juga diajarkan beberapa keahlian di dalam LPKA seperti mencukur rambut, mekanik, kelistrikan, dan kreativitas lainnya. Sehingga diharapkan nantinya setelah warga binaan bebas atau keluar dari LPKA mereka dapat mengaplikasikan ilmu-ilmu yang di dapat dari dalam LPKA ke lingkungan luar. LPKA berisi anak dengan status tahanan dan narapidana.

Penelitian dilakukan dengan mewawancarai secara mendalam dua orang subyek penelitian. Wawancara terhadap subyek dilakukan sebanyak lima (5) kali. Hasil wawancara peneliti rangkum sebagai berikut :

\section{Tabel 2 .Gambaran Subyek}

\begin{tabular}{|c|c|c|c|c|c|l|}
\hline Inisial & Usia & $\begin{array}{c}\text { Pendidikan } \\
\text { terakhir }\end{array}$ & $\begin{array}{c}\text { Anak } \\
\text { ke }\end{array}$ & Domisili & Vonis & $\begin{array}{l}\text { Gambaran } \\
\text { fisik }\end{array}$ \\
\hline JL & 16 thn & SD & 1 dari 3 & Pekanbaru & 2 thn & $\begin{array}{l}\text { Bertubuh } \\
\text { kecil dan } \\
\text { kurus }\end{array}$ \\
\hline FN & 15 thn & SD & 3 dari 4 & Siak & $\begin{array}{c}1 \text { thn } 8 \\
\text { bln }\end{array}$ & $\begin{array}{l}\text { Bertubuh } \\
\text { kecil dan } \\
\text { kurus }\end{array}$ \\
\hline
\end{tabular}

Sumber : Hasil olahan penelitian. 
Dari data di atas dapat dilihat usia, pendidikan terakhir, status anak dalam keluarga, domisili vonis dan gambaran fisik subyek. Hasil wawancara terhadap subyek, orang tua dan pegawai LPKA dirangkum dalam table berikut :

\section{Tabel 3 . Rangkuman Wawancara Subyek}

\begin{tabular}{|c|c|c|c|}
\hline \multirow[t]{2}{*}{ No } & \multirow[t]{2}{*}{ Jenis Pertanyaan } & \multicolumn{2}{|c|}{ Jawaban } \\
\hline & & JL & FN \\
\hline 1. & $\begin{array}{l}\text { Kisah singkat } \\
\text { awal mula } \\
\text { mengenal } \\
\text { perilaku sodomi }\end{array}$ & $\begin{array}{l}\text { Saya tinggal didaerah padat } \\
\text { penduduk dan dekat dengan } \\
\text { pasar. Banyak anak-anak } \\
\text { punk yang berada didaerah } \\
\text { tempat tinggal saya. Suatu } \\
\text { hari saat saya sedang } \\
\text { bermain bersama teman, } \\
\text { saya dipanggil seorang yang } \\
\text { saya sebut abang yang } \\
\text { merupakan anak punk ke } \\
\text { toilet umum yang sudah } \\
\text { agak rusak. Saya dipaksa } \\
\text { membuka celana dan dia } \\
\text { meraba serta memasukkan } \\
\text { alat kelaminnya didubur } \\
\text { saya. Saya berontak dan } \\
\text { melawan tapi abang } \\
\text { bertubuh cukup besar } \\
\text { sehingga saya tidak bisa } \\
\text { apa-apa. Dubur saya terasa } \\
\text { sakit selama beberapa hari } \\
\text { setelah itu. Saya diancam }\end{array}$ & $\begin{array}{l}\text { Pada suatu hari saat saya } \\
\text { masih kelas } 5 \text { SD, orang tua } \\
\text { tidak bisa mengantar saya ke } \\
\text { sekolah, sehingga saya harus } \\
\text { ke sekolah sendiri. Sekolah } \\
\text { saya jauh sekitar } 5 \text { km dari } \\
\text { rumah jadi saya harus } \\
\text { menggunakan angkutan kota } \\
\text { atau menumpang pada } \\
\text { seseorang. Pada hari itu saat } \\
\text { saya sedang menunggu } \\
\text { angkot, lewat seorang bapak } \\
\text { berperawakan besar naik } \\
\text { motor dan menawarkan saya } \\
\text { tumpangan. Hari itu saya } \\
\text { diantarkan dengan selamat } \\
\text { ke sekolah. Kemudian } \\
\text { beberapa hari setelahnya, } \\
\text { saya menumpang bapak itu } \\
\text { lagi untuk diantar ke } \\
\text { sekolah, tetapi sebelum } \\
\text { sampai sekolah bapak tsb }\end{array}$ \\
\hline
\end{tabular}




\begin{tabular}{|c|c|c|c|}
\hline & & $\begin{array}{l}\text { akan dibunuh jika } \\
\text { menceritakan kejadian tsb } \\
\text { kepada orang lain. Dua } \\
\text { minggu setelah itu, abang } \\
\text { mengajak saya menonton } \\
\text { video porno homo seksual } \\
\text { melalui hp. Setelah itu saya } \\
\text { dan dia melakukan seperti } \\
\text { yang kami tonton tapi } \\
\text { sebenarnya saya merasa } \\
\text { tidak suka dan marah. } \\
\text { Hanya saya tidak berani } \\
\text { melawan karena takut. } \\
\text { Orang tua saya bekerja } \\
\text { sebagai tukang jahit } \\
\text { sehingga tidak mengetahui } \\
\text { apa yang saya kerjakan } \\
\text { bersama teman-teman. Sejak } \\
\text { kejadian kedua tsb, saya jadi } \\
\text { tahu tentang sodomi. }\end{array}$ & $\begin{array}{l}\text { berhenti disuatu masjid. } \\
\text { Saya di ajak menuju toilet } \\
\text { masjid kemudian celana } \\
\text { saya dibuka dan bapak } \\
\text { tersebut memasukkan alat } \\
\text { kelaminnya ke dubur saya. } \\
\text { Saya menangis karena takut } \\
\text { dan merasa sakit tapi tidak } \\
\text { bisa berbuat apa-apa. } \\
\text { Setelah itu saya ditinggalkan } \\
\text { disana sendiri dan saya } \\
\text { berjalan kaki ke sekolah. } \\
\text { Seminggu setelah itu saya } \\
\text { bertemu lagi dengan bpk tsb } \\
\text { dan juga mengalami hal } \\
\text { yang sama tapi setelah itu } \\
\text { dia mengantarkan saya ke } \\
\text { sekolah. Setelah kejadian } \\
\text { kedua tsb, saya mencari info } \\
\text { di internet tentang hal yang } \\
\text { saya alami. Saya membuka } \\
\text { situs porno tentang adegan } \\
\text { yang saya alami.Sejak itu } \\
\text { saya tahu sodomi. }\end{array}$ \\
\hline 2. & $\begin{array}{c}\text { Bagaimana } \\
\text { perasaan saat } \\
\text { menjadi korban } \\
\text { sodomi? }\end{array}$ & $\begin{array}{l}\text { Sangat marah dan takut } \\
\text { serta malu. }\end{array}$ & $\begin{array}{l}\text { Pertama kali saya sangat } \\
\text { marah dan benci pada bapak } \\
\text { tsb tapi saya tidak bisa apa- } \\
\text { apa, saya takut.Dia } \\
\text { mengancam }\end{array}$ \\
\hline
\end{tabular}




\begin{tabular}{|c|c|c|c|}
\hline & & & $\begin{array}{l}\text { mencelakai saya jika } \\
\text { memberitahu ke orang lain. }\end{array}$ \\
\hline 3. & $\begin{array}{c}\text { Apakah ada } \\
\text { perubahan pada } \\
\text { diri saudara } \\
\text { setelah kejadian } \\
\text { tsb? }\end{array}$ & $\begin{array}{l}\text { Saya jadi merasa rendah diri } \\
\text { dan tidak lagi pergi ke } \\
\text { sekolah. }\end{array}$ & $\begin{array}{l}\text { Saya menjadi orang yang } \\
\text { pemarah, sering murung } \\
\text { merasa hina dan rendah. }\end{array}$ \\
\hline 4. & $\begin{array}{l}\text { Apakah tidak } \\
\text { memberitahu } \\
\text { kepada orang tua } \\
\text { dan keluarga? }\end{array}$ & Tidak, saya takut dan malu. & Tidak, saya tidak berani. \\
\hline 5. & $\begin{array}{c}\text { Apa yang } \\
\text { mendorong } \\
\text { saudara } \\
\text { melakukan } \\
\text { perbuatan } \\
\text { sodomi tsb } \\
\text { kepada orang } \\
\text { lain? }\end{array}$ & $\begin{array}{l}\text { Saya merasa dendam dan } \\
\text { harus melampiaskannya } \\
\text { kepada anak lain. Saya juga } \\
\text { mulai teringat terus adegan- } \\
\text { adegan di video porno yang } \\
\text { saya lihat. }\end{array}$ & $\begin{array}{l}\text { Awalnya saya memiliki } \\
\text { dendam tiap ingat kejadian } \\
\text { pertama kali saya disodomi } \\
\text { sehingga saya ingin } \\
\text { melampiaskannya juga } \\
\text { kepada orang lain, tapi saya } \\
\text { tidak berani.Makanya saat } \\
\text { melihat anak kecil berusia } 4 \\
\text { thn, keberanian saya timbul. } \\
\text { Selain itu juga karena saya } \\
\text { mulai ketagihan melihat } \\
\text { video porno laki-laki sesama } \\
\text { lelaki berhubungan seks } \\
\text { maka saya juga jadi } \\
\text { memiliki keinginan untuk } \\
\text { melakukannya. }\end{array}$ \\
\hline 6. & $\begin{array}{c}\text { Berapa kali } \\
\text { saudara menjadi }\end{array}$ & 2 kali & 4 kali \\
\hline
\end{tabular}




\begin{tabular}{|c|c|c|c|}
\hline 7. & korban sodomi ? & \\
\hline & Berapa kali & 2 kali & 1 kali \\
& saudara & & \\
melakukan & & \\
& sodomi pada & & \\
& orang lain? & & \\
\hline
\end{tabular}

\section{Sumber : Olahan Data Penelitian.}

Pengolahan data untuk mendapatkan hasil penelitian adalah menggunakan triangulasi, yaitu mensesuaikan data primer berupa wawancara subyek dengan data yang didapatkan melalui wawancara orang tua dan petugas LPKA. Hal ini dilakukan untuk mendapatkan hasil yang valid, rangkuman wawancara sebagai berikut

Tabel 4. Wawancara Orang Tua Subyek

\begin{tabular}{|c|c|c|c|}
\hline No & Jenis Pertanyaan & Orang Tua JS & Orang Tua FN \\
\hline 1. & $\begin{array}{c}\text { Apakah } \\
\text { pekerjaan bapak } \\
\text { dan ibu? }\end{array}$ & $\begin{array}{l}\text { Bapak sebagai tukang jahit } \\
\text { rumahan, ibu sebagai IRT }\end{array}$ & $\begin{array}{l}\text { Ayah dan ibu bekerja di } \\
\text { kebun sawit milik orang } \\
\text { lain. }\end{array}$ \\
\hline 2. & $\begin{array}{c}\text { Bagaimana } \\
\text { gambaran } \\
\text { perilaku subyek? }\end{array}$ & $\begin{array}{l}\text { JS merupakan anak yang } \\
\text { nakal karena susah disuruh } \\
\text { sekolah dan selalu bermain } \\
\text { diluar rumah. Tapi JS tidak } \\
\text { pernah berbuat kriminal } \\
\text { seperti narkoba dimana } \\
\text { tempat tinggal kami } \\
\text { merupakan pusat } \\
\text { perdagangan barang haram } \\
\text { tsb. Karena badannya lebih } \\
\text { kecil dari teman seusia nya, } \\
\text { JS lebih sering bermain } \\
\text { dengan anak-anak yang }\end{array}$ & $\begin{array}{l}\text { FN merupakan anak yang } \\
\text { baik dan selalu menurut apa } \\
\text { kata orang tua. Dia dan } \\
\text { saudara kandungnya biasa } \\
\text { melakukan pekerjaan rumah } \\
\text { karena kami bekerja di } \\
\text { kebun. Biasanya FN dan } \\
\text { saudaranya pergi ke sekolah } \\
\text { bersama kakak tertuanya. }\end{array}$ \\
\hline
\end{tabular}




\begin{tabular}{|c|c|c|c|}
\hline & & usianya lebih muda. & \\
\hline 3. & $\begin{array}{c}\text { Apakah } \\
\text { pendidikan } \\
\text { subyek pada saat } \\
\text { ditangkap? }\end{array}$ & Kelas 2 SMP & Kelas 1 SMP \\
\hline 4. & $\begin{array}{l}\text { Apakah pernah } \\
\text { melihat } \\
\text { perubahan } \\
\text { perilaku subyek } \\
\text { dalam } 5 \text { tahun } \\
\text { terakhir? }\end{array}$ & $\begin{array}{l}\text { Ibu nya pernah cerita pada } \\
\text { saya bahwa JS terlihat } \\
\text { sering murung dan marah } \\
\text { tanpa sebab. Tapi karena } \\
\text { saya sangat sibuk, saya } \\
\text { anggap itu hanya hal biasa. }\end{array}$ & $\begin{array}{l}\text { Pernah kami lihat dia lebih } \\
\text { murung akhir-akhir ini. } \\
\text { Sering menyendiri dan } \\
\text { malas pergi ke sekolah. }\end{array}$ \\
\hline 5. & $\begin{array}{c}\text { Bagaimana } \\
\text { perasan saat } \\
\text { mengetahui } \\
\text { pertama kali? }\end{array}$ & $\begin{array}{l}\text { Kami sekeluarga sangat } \\
\text { terkejut, marah dan malu. } \\
\text { Korban yang berusia } 5 \\
\text { tahun merupakan tetangga } \\
\text { kami juga. Tapi nasi sudah } \\
\text { menjadi bubur.Tidak bisa } \\
\text { apa-apa lagi. }\end{array}$ & $\begin{array}{l}\text { Takut, kaget dan malu. } \\
\text { Apalagi korban merupakan } \\
\text { tetangga belakang rumah. }\end{array}$ \\
\hline 6. & $\begin{array}{c}\text { Apakah harapan } \\
\text { terhadap subyek } \\
\text { untuk } \\
\text { kedepannya? }\end{array}$ & $\begin{array}{l}\text { Kami sudah tidak marah } \\
\text { lagi bahkan kami merasa } \\
\text { menyesal karena kesalahan } \\
\text { JS juga akibat dari } \\
\text { kurangnya perhatian kami. } \\
\text { Kami berharap, setelah } \\
\text { keluar dari penjara JS dapat } \\
\text { melanjutkan sekolah lagi } \\
\text { dan hidup normal. }\end{array}$ & $\begin{array}{l}\text { Kami berharap FN bisa } \\
\text { kembali sekolah dan } \\
\text { melupakan kejadian ini. } \\
\text { Supaya bisa kembali hidup } \\
\text { normal. }\end{array}$ \\
\hline
\end{tabular}

Sumber : Olahan Data Penelitian. 
Tabel 5. Wawancara Petugas LPKA

\begin{tabular}{|c|c|c|c|}
\hline No & Jenis Pertanyaan & JS & FN \\
\hline 1. & $\begin{array}{c}\text { Berdasarkan } \\
\text { laporan P2TP2A } \\
\text { yang menjadi } \\
\text { lembaga } \\
\text { perlindungan } \\
\text { anak, apa } \\
\text { penyebab pelaku } \\
\text { melakukan } \\
\text { sodomi terhadap } \\
\text { korban? }\end{array}$ & $\begin{array}{l}\text { Untuk kasus JS, penyebabnya } \\
\text { adalah pelaku merasa dendam dan } \\
\text { sakit hati pada perlakuan yang } \\
\text { diterimanya saat kecil sehingga } \\
\text { merasa harus melampiaskan pada } \\
\text { orang lain. Pelaku juga ketagihan } \\
\text { menonton video porno. Pelaku } \\
\text { melihat anak-anak yang usianya } \\
\text { lebih muda lebih mudah untuk di } \\
\text { intimidasi. }\end{array}$ & $\begin{array}{lr}\text { Pelaku } & \text { ingin } \\
\text { membalaskan } & \\
\text { dendamnya } & \text { yang } \\
\text { telah } & \text { berjalan } \\
\text { selama } 2 & \text { tahun. } \\
\text { Kebetulan } & \text { anak } \\
\text { yang } & \text { menjadi } \\
\text { korban } & \text { sering } \\
\text { pelaku } & \text { lihat } \\
\text { bermain } & \text { sendiri di } \\
\text { halaman } & \text { rumah. } \\
\text { Pelaku } & \text { sering } \\
\text { melihat video porno } \\
\text { di hp } \\
\text { warnet. }\end{array}$ \\
\hline 2. & $\begin{array}{c}\text { Apakah } \\
\text { pembinaan yang } \\
\text { dilakukan pada } \\
\text { pelaku selama } \\
\text { berada di LPKA } \\
\text { ? }\end{array}$ & $\begin{array}{l}\text { Pembinaan biasa seperti TPA dan } \\
\text { pelatihan keterampilan yang } \\
\text { menjadi kegiatan umum di LPKA }\end{array}$ & $\begin{array}{l}\text { Pembinaan biasa } \\
\text { seperti TPA dan } \\
\text { pelatihan } \\
\text { keterampilan yang } \\
\text { menjadi kegiatan } \\
\text { umum di LPKA }\end{array}$ \\
\hline
\end{tabular}

Sumber : Olahan Data Penelitian.

Berdasarkan tabel 2, hasil wawancara terhadap identitas diri pelaku dapat digambarkan bahwa pelaku berusia remaja. Pada saat melakukan kejahatan, pelaku merupakan siswa sekolah menengah.
Pendidikan terakhir kedua pelaku adalah tamat SD. Pelaku JS merupakan anak sulung dari 3 bersaudara, sedangkan FN memiliki 2 kakak perempuan dan 1 adik laki-laki. JS tinggal dengan keluarga dan 
berdomisili di Kota Pekanbaru, sedangkan FN tinggal dengan keluarga dan berdomisili di Siak. Gambaran fisik kedua pelaku adalah bertubuh kecil dan kurus.

Pada tabel 3, digambarkan bahwa kedua pelaku pertama kali menjadi korban sodomi orang dewasa..JS menjadi korban sodomi yang dilakukan seseorang yang dikenalnya dan FN disodomi oleh orang dewasa yang dikenal sepintas. Kedua subyek menjadi korban kekerasan seksual saat berusia 10 dan 11 tahun. Subyek di ancam dan diintimidasi untuk tidak menceritakan kejahatan yang mereka alami. Usia yang sangat muda dan ketakutan akan ancaman menjadikan subyek memendam rasa benci terhadap apa yang dialami. Karena malu dan takut, subyek mencari tahu sendiri melalui internet tentang hal yang dialaminya.

Tidak adanya bimbingan dalam mencari informasi menjadikan subyek mendapatkan informasi melalui video porno yang dilihat di handphone maupun warnet. Hal ini menjadi pengaruh buruk bagi subyek karena mulai ketagihan melihat video porno yang berisi hubungan seks sejenis. Akibat dari dendam masa lalu dan pengaruh buruk pornografi mendorong subyek untuk melampiaskannya kepada orang lain. Ketika kesempatan muncul, seperti saat melihat anak kecil yang bermain sendirian, saat itu subyek melancarkan aksinya. JS telah melakukan aksinya sebanyak 2 kali sedangkan FN 1 kali sebelum tertangkap.

Tabel 4 dan 5 berisi rangkuman wawancara orang tua pelaku dan petugas LPKA. Berdasarkan wawancara didapatkan hasil bahwa kedua orang tua subyek kurang memberikan perhatian terhadap perkembangan anak-anak. Hal ini terjadi akibat kesibukan pekerjaan. Orang tua JS keduanya terlalu sibuk dengan usaha jahitan dan orang tua FN bekerja di kebun yang lokasinya jauh dari rumah. Keadaan ini juga yang menjadi peluang bagi orang dewasa untuk leluasa melakukan kejahatan terhadap anak.

Hasil wawancara yang didapat dari petugas LPKA, dimana laporan hasil analisa P2TP2A Kota Pekanbaru menyatakan bahwa subyek awalnya 
merupakan korban sodomi yang dilakukan orang dewasa. Selama berada dalam tahanan, subyek tidak mendapatkan pembinaan khusus dan hanya mendapatkan pembinaan seperti tahanan lain.

\section{Hasil Penelitian}

Berdasarkan penelitian yang telah dilakukan, maka disimpulkan hasil penelitian adalah :

1. Gambaran pelaku sodomi yang berada di LPKA Pekanbaru adalah remaja laki-laki berusia 15 tahun dan 16 tahun, tamat SD dan saat ditangkap sedang duduk di bangku SMP dan berperawakan kecil dan kurus.

2. Faktor penyebab remaja melakukan tindak kejahatan sodomi adalah karena pelaku awalnya merupakan korban kekerasan seksual sodomi yang dilakukan oleh orang dewasa. Perasaan dendam menjadikan pelaku melampiaskannya kepada orang lain yang berusia lebih muda. Selain itu juga seringnya menonton video porno hubungan seks sejenis menjadikan pelaku merasa ingin mempraktekkannya. Pengawasan orang tua yang tidak dipenuhi juga menjadi faktor terbukanya peluang kejahatan bagi anak-anak.

Pembinaan yang kurang tepat sasaran selama berada di LPKA menjadikan remaja pelaku sodomi tidak mendapatkan hak-hak nya. Seharusnya remaja pelaku sodomi mendapatkan pembinaan psikologis agar trauma masa lalu sebagai korban dapat dihilangkan. Hal ini penting bagi membantu pelaku menjalani kehidupan masa depan yang lebih baik.

\section{Kesimpulan}

Perilaku menyimpang sodomi memang menjadi suatu bentuk kejahatan yang saat ini mewabah baik di skala nasional maupun internasional. Bahkan pelaku tidak saja merupakan orang dewasa tetapi juga dilakukan oleh remaja, dimana seharusnya remaja tersebut sedang menjalani proses perkembangannya. 
Banyak faktor yang melatar belakangi remaja melakukan kejahatan tersebut. Selama ini, penelitian berfokus hanya pada korban dan tidak meneliti lebih dalam terhadap faktor pelaku.

Peneliti berharap pada penelitian berikutnya agar dilakukan kajian mendalam terhadap pelaku sodomi dan bagaimana menyikapi agar perilaku tersebut dapat hilang. Sosialisasi bagi peran orang tua juga seharusnya diberikan untuk menghindari terbukanya peluang kejahatan pada anak. Selain itu, peran LPKA dan pemerintah juga diharapkan dalam memberikan perhatian terhadap pembinaan psikologis remaja pelaku sodomi. 


\section{Daftar Pustaka}

Alsa, A. (2003). Pendekatan kuantitatif dan kualitatif serta kombinasinya dalam penelitian psikologi (satu uraian singkat dan contoh berbagai tipe penelitian). Yogyakarta. Pustaka Pelajar.

Hurairah, Abu. (2012). Kekerasan Terhadap Anak. Bandung: Nuasa Press.

Noviana, I. (2015). Kekerasan Seksual Terhadap Anak: Dampak Dan Penanganannya, Socio Informa, Vol,01, No.1, Januari-April.

Q.S. Al-A'raf : 80-81.

Q.S. Hud :82.

Sari. (2009). Kekerasan Seksual Pada Anak. Buku saku kesehatan, pediatric. Edisi 5. Jakarta.

Sarwono. (2012). Psikologi Remaja. Edisi Revisi, Rajawali Pers.

Weber, Reese., Smith, Dana M.(2010).

Outcomes of Child Sexual Abuse as

Predictors of laters Sexual Victimization. Journal of International

Violence. (Online). 26 (9): 1899-1905. 